\title{
Effects of Diet and Time on Feed on Fatty Acid Composition in Muscle of Charolais Steers
}

\author{
N. -J. Choi*, **, S. W. Kang*, E. G. Kwon*, W. M. Cho*, B. S. Jeon* and B. K. Park*
}

Hanwoo experiment station, National Livestock Research Institute, RDA*

Dept. of Animal Science and Microbiology, Institute of Grassland and Environmental Research, UK**

$$
\begin{gathered}
\text { 사료급원과 급여기간이 Charolais 거세우 근내 지방산 조성에 } \\
\text { 미치는 영향 } \\
\text { 최낙진*,** . 강수원* · 권응기* · 조원모* · 전병수* . 박병기* }
\end{gathered}
$$

축산연구소, 한우시험장*, 환경초지연구소, 미생물 \& 동물영양생리과, 영국**

$$
\text { 요 약 }
$$

본 시험은 n-6 및 n-3 계열 다중불포화지방산 함량이 풍부한 사료원을 Charolais 거세우에게 각각 사료 급여기간을 달리하여 급여하였을 때 근내 지방산 조성을 조사하기 위하여 수행하였다. 시험 수 행은 영국 IGER (Institute of Grassland and Environmental Research) 연구소 육우 사양실험실에서 실시 하였으며, 공시축은 총 28두 Charolais 거세우로서 ad libitum으로 조사료 급여를 하였다. 그리고, 두 개 의 지방원료원으로서 C18:2 n-6 함량이 풍부한 대두와 C18:3 n-3함량이 풍부한 아마종실을 60일 및 90 일간 공급하였으며, 농후사료는 총 건물섭취의 $73 \%$ 으로 하였다. 도체중, conformation 및 fatness score는 60 일 사료급여구와 비교하여 90 일 사료급여구에서 높게 조사되었다 $(\mathrm{P}<0.05)$. 공시축의 m. longissimus thoracis의 중성지방내 총지방산 함량은 지방원료원에 의한 영향은 없었지만, 반면에 인지질 내 총지 방산 함량은 아마종실 급여구에 대략 $15 \%$ 높게 나타났다 $(\mathrm{P}<0.05)$. 근육 중성지방 내 $\mathrm{C} 18: 3 \mathrm{n}-3$ 와 cis-9, trans-11 CLA 함량은 아마종실급여구에 유의성있게 높게 조사되었으며 $(\mathrm{P}<0.001)$, 반면에 C18:2 n-6 함량은 대두 급여구에서 높았다 $(\mathrm{P}<0.001)$. 근육 인지질 내 CLA와 C18:3 함량은 아마종실급여구 에 높게 나타났으며, C18:2 n-6 함량은 대두 급여구에 높았다. 한편, 근육 중성지방 내 C14:0, C16:0, C16:1, CLA, C18:1 n-9, C18:2 n-6 및 C18:3 n-3 함량은 90일 사료급여구에서 높게 조사되었다. 근내 불포화지방산 : 포화지방산 비율은 사료급여기간에 영향을 받지 않았지만, C18:2 n-6:C18:3 n-3 비율과 n-6:n-3 불포화지방산 비율은 아마종실 급여구에서 높게 나타났다. 따라서 본 시험은 대두 혹은 아마 종실 같은 사료급여와 급여기간에 의하여 쇠고기 근내 불포화지방산 함량을 변화 시킬 수 있음을 보 여주고 있다. 그리고, 아마종실 급여는 쇠고기 내 지방산 함량이 조성이 인체 건강과 관련한 영양적 지표에 보다 바람직한 것으로 증명되었다.

(Key words : Beef, Lipids, Polyunsaturated fatty acids)

\section{I . INTRODUCTION}

The fatty acid composition of ruminant products has become increasingly important in recent years as the interactions between nutrition and a number of lifestyle diseases such as heart disease

Corresponding author : Dr Choi Nag-Jin, Hanwoo experiment station, National Livestock Research Institute, RDA, Pyoungchang, Kwangwon-do, Korea

Tel : 033-330-0654, Fax : 033-330-0660, E-mail : nagjin@rda.go.kr 
and cancer has become more apparent. Modern beef is a low fat food $(<5 \%$ fat), however mainly due to ruminal biohydrogenation of dietary unsaturated fatty acids the fatty acid composition of beef is relatively saturated (approximately 0.45-0.50). However, beef is a natural carrier of beneficial n-3 polyunsaturated fatty acids (PUFA) and conjugated linoleic acid (particularly cis-9, trans-11 CLA). There is much interest in further promoting the nutritional balance in beef, i.e. increase the ratio of PUFA : saturated fatty acids (P:S), reducing the ratio of $n-6: n-3$ PUFA. Our previous studies have demonstrated the benefits of feeding diets which are rich in n-3 PUFA such as grass, linseed or fish oil (Enser et al., 1998; Choi et al., 2000, Scollan et al., 2001a). Breeds may also differ in the balance of fatty acids in muscle, ie. beef $\mathrm{v}$. dairy breeds (Choi et al., 2000).

In our previous studies (Choi et al., 2000; Scollan et al., 2001a) although feeding linseed or fish oil resulted in significant and beneficial increases of n-3 PUFA into muscle, the efficiency of transfer of dietary PUFA into bovine tissues was poor due to extensive biohydrogenation in the rumen (Scollan et al., 2001b). Feeding higher proportions of concentrates may help to improve the rumen bypass of PUFA since it has been demonstrated that the lower $\mathrm{pH}$ levels on feeding high levels of concentrates may help to reduce the extent of biohydrogenation (Van Nevel and Demeyer, 1996a).

The polyunsaturated fatty acid (PUFA) composition of ruminant tissues is affected by differences between the metabolism of linoleic acid (C18:2 n-6) and a-linolenic acid (C18:3 n-3) in both the rumen and at the tissue level. It is recognised that C18: $2 \mathrm{n}-6$ and C18:3 n-3 act as precursors for the biosynthesis of $n-6$ and $n-3$ longer chain fatty acids, respectively (Hansen, 1994) but few studies in ruminants have examined how the balance of dietary fatty acids (i.e n- 6 v. n-3 PUFA) may affect the resultant fatty acid composition of beef (including CLA).

Time on feed (TOF) is also known to affect fatty acid composition in bovine tissue. The amounts of total PUFA decreased and unsaturated fatty acids, particularly C18: $1 \mathrm{n}-9$, increased in bovine tissues with time on feed (Duckett et al., 1993; Rule et al., 1997). Changes in overall fatty acid composition in bovine tissues mainly result from decreases in C18:0 and increases in C18:1 n-9 with TOF according to some studies (Duckett et al., 1993; Rule et al., 1997). The effect of age on fatty acid composition in beef is also related to body fatness (Robelin, 1986; HuertaLeidenz et al., 1996). As the animals grow, there is an apparent increase in unsaturation and a corresponding decrease in the saturation of muscle (Hecker et al., 1975) and adipose tissue (Link et al., 1970; Hecker et al., 1975; Westerling and Hedrick, 1979).

The objectives of this experiment were to investigate the fatty acid composition of the neutral lipid and phospholipid fractions from the $m$. longissimus thoracis and subcutaneous fat of Charolais steers fed on diets containing different lipid sources. The diets were based on full fat soya (rich in C18:2 n-6) and linseed (rich in C18:3 n-3) offered as part of a high concentrate feeding regime, with a target concentrates to forage ratio of $0.8: 0.2$ for either 60 or 90 days.

\section{MATERIALS \& METHODS}

\section{Experimental design and treatments}

Twenty-eight Charolais steers with an initial live weight of $548 \mathrm{~kg}$ (s.e. 10.0) were randomly allocated to one of two dietary treatments for either 60 or 90 days in IGER (Institute of Grassland and Environmental Research, UK), resulting in 7 animals per treatment group. The 
diets were forage (mixture of grass silage and barley straw, 50:50 ratio on a DM basis) and one of two experimental concentrates which were based on wheat, molassed sugarbeet and molasses with differing sources of lipid: Diet 1 whole linseed(n-3 PUFA source, high in C18:3 n-3) and Diet 2 full fat soya bean (n-6 PUFA source, high in C18:2 n-6). The formulation of the concentrates is given in Table 1 . The animals were fed ad libitum on forage and concentrates to achieve approximately 0.2 and 0.8 of the dietary dry matter (DM) intake, respectively. Diets were formulated so that total dietary oil intake was $7 \%$, of which approximately $3.5 \%$ was from the experimental test oil source. Vitamin $\mathrm{E}$ was added to the concentrates at a calculated level of $345 \mathrm{IU} / \mathrm{kg}$ DM as dl-atocopheryl acetate.

Table 1. Formulation and chemical composition of the forage and concentrates used in the experimental diets

\begin{tabular}{|c|c|c|c|}
\hline & \multirow{2}{*}{ Forage } & \multicolumn{2}{|c|}{ Concentrate } \\
\hline & & Soya & Linseed \\
\hline & \multicolumn{3}{|c|}{ g/kg fresh } \\
\hline \multicolumn{4}{|l|}{ Ingredient } \\
\hline Wheat & & 425 & 425 \\
\hline Molassed sugar-beet pulp & & 220 & 220 \\
\hline Molasses & & 50 & 50 \\
\hline Full fat Soya-bean meal & & 280 & 0 \\
\hline Linseed & & 0 & 125 \\
\hline Linseed meal & & 0 & 155 \\
\hline \multirow[t]{2}{*}{ Minerals plus vitamins } & & 25 & 25 \\
\hline & \multicolumn{3}{|c|}{$g / k g D M$} \\
\hline \multicolumn{4}{|l|}{ Chemical composition } \\
\hline Dry matter & 491.7 & 890.5 & 897.7 \\
\hline $\mathrm{pH}$ & 4.49 & - & - \\
\hline Total nitrogen & 17.2 & 32.6 & 29.7 \\
\hline Organic matter & 939.6 & 925.0 & 922.7 \\
\hline Neutral detergent fibre & 713.2 & 204.3 & 274.5 \\
\hline Water soluble carbohydrate & 34.3 & - & - \\
\hline Acid hydrolysis ether extract & 16.6 & 88.6 & 83.1 \\
\hline
\end{tabular}

\section{Procedures and measurements}

Animals within a treatment group were penned together. Animals were individually fed using roughage intake control feeders and concentrate feeders (Insentec, inc, Holland) and had free access to fresh water. At the beginning of the experiment, during a 21-day preliminary period, all animals were gradually introduced to the experimental forage offered ad libitum and a standard commercial concentrate to achieve approximately 0.8 of DM intake. At the end of this 21-day preliminary period live weight was measured on 3 consecutive days. The animals were then introduced to their allocated dietary concentrate over a 7-day period. During the main experimental period, feed intake was recorded daily and animals were weighed every 4 weeks on 2-days consecutively. All weighings were conducted at the same time of day (14:30 h) to reduce variations due to diurnal patterns of feed intake.

Forage was fed at 09:00 $\mathrm{h}$ daily, and the concentrates in two equal proportions at 09:00 and 16:30 h. The forage and concentrates were sampled 3 times per week for DM analysis in a forced-air oven at $105^{\circ} \mathrm{C}$. Forage was offered at 1.1 times the previous allocation. Concentrates feed levels were adjusted weekly, based on the previous week's forage consumption. Samples of forage and concentrates were accumulated over 4-week periods and stored frozen $\left(-20^{\circ} \mathrm{C}\right)$ to await assessment of chemical composition.

\section{Analytical methods}

Feed samples were analysed for DM, OM, total nitrogen, ammonia nitrogen, NDF, ADF, acetic acid, $\mathrm{pH}$ and oil content as described by Choi et al. (2000). The analytical methods of fatty acid in muscle and adipose tissue were also described by Choi et al. (2000). However, the 
diet samples were treated with alkali to obtain the fatty acids directly in this experiment.

The animals remained on treatment for their allocated time period, either 60 or 90 days. Seven animals were slaughtered each week over a 4-week period. Animals were selected for slaughter on a live-weight basis; the one or two heaviest animals in each group were selected for slaughter each week. Animals were transported from Aberystwyth to the University of Bristol on the day before slaughter and were kept in lairage overnight with access to water and slaughtered conventionally using captive bolt stunning. Carcasses were held in chill $\left(1-2^{\circ} \mathrm{C}\right)$ for $48 \mathrm{~h}$ before butchering and sampling. Cold carcass weights (excluding kidney knob and channel fat), external fatness and conformation scores were assessed by the method of Kempster et al. (1986)

Fatty acid composition results are given as proportion times 100 and muscle fatty acid content as mg of fatty acid per $100 \mathrm{~g}$ wet tissue, quantified by reference to the internal standard. Only the major fatty acids and minor components readily-identified and relevant to the study are reported; representing over 0.9 of the total fatty acids present. The fatty acid reported as C16:1 cis consists of both the $n-9$ and n-7 isomers and a contaminating branched seventeen carbon fatty acid. The trans C18:1 isomers are incompletely resolved by this column and are reported as one value.

\section{Calculations and Statistical analysis}

Live-weight growth rates (g/d) for each animal were calculated by regression of live-weight on time, and average daily feed intakes were calculated for the individual animals. Visual scores for carcass fatness and conformation were carried out using the EU system (Kempster et al., 1986) and were converted to numerical values before analysis by multiplying the values for estimated subcutaneous fat and conformation by ten. All the data was subjected to analysis of variance to identify diet, TOF and interaction effects (Genstat 5; Lawes Agricultural Trust, 1990).

\section{RESULTS}

\section{Diet composition}

The chemical composition and fatty acid composition of the experimental diets are presented in Table 1 and 2, respectively. The DM and NDF content of the forage were high and the total nitrogen low reflecting the high proportion of straw in the forage mix. The total nitrogen and oil content were higher and NDF lower in the soya compared with the linseed-based concentrate. Total fatty acid content of the forage was $10.7 \mathrm{~g} / \mathrm{kg} \mathrm{DM}$, of which 0.38 was C18:3 n-3 (Table 2), which again relates to the inclusion of straw in the forage mix, since the normal portion of $\mathrm{C} 18: 3 \mathrm{n}-3$ in grass silage typically ranges between 0.5-0.6. In the concentrate diets, the amount of saturated fatty acids (C14:0, C16:0

Table 2. Fatty acid composition of the components

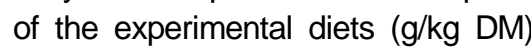

\begin{tabular}{lrrr}
\hline & & \multicolumn{2}{c}{ Concentrate } \\
\cline { 3 - 4 } & & Soya & Linseed \\
\hline \hline C14:0 & 0.18 & 0.12 & 0.41 \\
C16:0 & 1.89 & 11.17 & 7.80 \\
C16:1 & 0.19 & 0.11 & 0.19 \\
C18:0 & 0.21 & 2.73 & 3.04 \\
C18:1 n-9 & 0.43 & 16.53 & 14.43 \\
C18:1 n-7 & 0.10 & 1.26 & 0.69 \\
C18:2 n-6 & 1.52 & 45.79 & 17.35 \\
C18:3 n-3 & 4.09 & 6.33 & 47.17 \\
Total fatty acids & 10.66 & 85.21 & 92.13 \\
\hline ND $=$ not detected & \multicolumn{3}{c}{} \\
The expressed individual fatty & acid and total fatty \\
acid are from soya, linseed and forage, respectively.
\end{tabular}


and C18:0) were 14.0 and $11.3 \mathrm{~g} / \mathrm{kg}$ in the soya and linseed, respectively. The total amount of the principle fatty acids, C18:2 n-6 and C18:3 n-3 were similar in the two concentrate diets. As expected, linseed was rich in C18:3 n-3 while soya was high in C18:2 n-6. The ratio of C18:2 n-6 : C18:3 n-3 was 7.23 and 0.37 on the soya and linseed concentrates, respectively. As DM intake was not influenced by diet or TOF (see below), fatty acid intake mirrored changes in the fatty acid composition of the diets. Averaged across both feeding periods (60 and 90 days), intake of C18:2 n-6 was 387 and 148 and that of C18:3 n-3 was 66 and 402 g/day on the soya and linseed treatments, respectively.

\section{Animal performance and carcass char- acteristics}

Animal performance and carcass classification data are presented in Table 3. The proportion of concentrate in the total DM intake averaged 0.73 across the treatments compared to a target proportion of 0.8 . Diet and TOF did not influence feed intake. Liveweight gain was higher in animals fed on soya but was not influenced by TOF. Feed conversion efficiencies were not influenced by diet or TOF and averaged $7.8 \mathrm{~kg} \mathrm{DM} / \mathrm{kg}$ liveweight gain.

Cold carcass weight, conformation and fatness scores were not affected by diet but were higher by on average, 7.9, 13.7 and $15.1 \%$ respectively, in the 90 compared to the 60 day feeding groups $(\mathrm{P}<0.05)$. Diet and TOF did not influence ultimate $\mathrm{pH}$, which averaged 5.55 overall.

\section{Fatty acid composition of muscle lipids}

The muscle content of neutral lipid and phospholipid fatty acids are expressed as mg per $100 \mathrm{~g}$ of muscle, and the fatty acid composition as proportion times 100. This data is presented

Table 3. Diet and time on feed (TOF) effects on animal performance and carcass classification scores, carcass cold weight and ultimate $\mathrm{pH}$ in Charolais steers fed on diets containing different sources of lipid

\begin{tabular}{|c|c|c|c|c|c|c|c|}
\hline & \multicolumn{2}{|c|}{ Soya } & \multicolumn{2}{|c|}{ Linseed } & \multirow[b]{2}{*}{ s.e.d } & \multicolumn{2}{|c|}{ Significance $^{1)}$} \\
\hline & 60 day & 90 day & 60 day & 90 day & & Diet & TOF \\
\hline Forage DM intake (kg/day) & 3.0 & 3.2 & 3.2 & 2.9 & 0.142 & NS & NS \\
\hline Concentrate DM intake (kg.day) & 8.4 & 8.3 & 8.3 & 8.2 & 0.096 & NS & NS \\
\hline Total DM intake (kg/day) & 11.4 & 11.5 & 11.5 & 11.1 & 0.142 & NS & NS \\
\hline Liveweight gain (kg/day) & 1.67 & 1.55 & 1.36 & 1.43 & 0.105 & $*$ & NS \\
\hline $\begin{array}{l}\text { Feed conversion efficiency } \\
\mathrm{kg} \mathrm{DM} \text { intake/ } \mathrm{kg} \text { liveweight gain }\end{array}$ & 7.2 & 7.5 & 8.8 & 7.8 & 0.536 & NS & NS \\
\hline Cold carcass weight $(\mathrm{kg})^{2)}$ & 181 & 199 & 180 & 193 & 9.34 & NS & * \\
\hline Conformation $^{3)}$ & 94 & 106 & 89 & 106 & 8.50 & NS & * \\
\hline Fatness ${ }^{3)}$ & 81 & 90 & 83 & 104 & 10.01 & NS & * \\
\hline Ultimate $\mathrm{pH}$ & 5.54 & 5.56 & 5.54 & 5.56 & 0.018 & NS & NS \\
\hline
\end{tabular}

1) In this and all other tables NS, *,** and *** refer to significance levels $\mathrm{P}>0.05, \mathrm{P}<0.05, \mathrm{P}<0.01$ and $\mathrm{P}<0.001$, respectively. There were no interactions between breed and feed. 60 and 90 day refer to length of time the animals remained on treatment.

2) half side weight

3) Fatness and conformation scores were converted to numerical values using the procedure of Kempster et al. (1986). 
in Tables 4 and 5, respectively. Diet did not influence total intramuscular fatty acid content of neutral lipid but total phospholipid fatty acid was approximately $15 \%$ higher in linseed compared with soya. Total intramuscular fatty acid content in neutral lipid was significantly higher in the 90 compared with $60 \mathrm{~d}$ treatments, approximately 2.9 and $3.9 \mathrm{~g}$ per $100 \mathrm{~g}$ muscle, respectively. However, TOF did not affect total phospholipid fatty acid content in the muscle. When averaged across TOF, the ratio of C18:2 n-6/C18:3 n-3 in the neutral lipid averaged 4.46 and 1.34 and in phospholipid 9.68 and 2.17 for soya and linseed treatments, respectively.

\section{Fatty acid composition of the muscle neutral lipid fraction}

The proportions of saturated, monounsaturated and polyunsaturated fatty acids in the neutral lipids when averaged across the treatments were $0.45,0.42$ and 0.02 . The major fatty acids in the neutral lipid fraction of each were C16:0, C18:0 and C18:1 n-9 which together contributed approximately 0.76 of the total neutral lipid fatty acids when averaged across all the treatments. The intramuscular neutral lipid fraction from animals fed on linseed contained a significantly higher content and proportion of C18:3 n-3 and

Table 4. Diet and time of feed (TOF) effects on fatty acid composition in neutral lipid of $\mathrm{m}$. longissimus thoracis tissue in Charolais steers fed on diets containing different sources of lipid

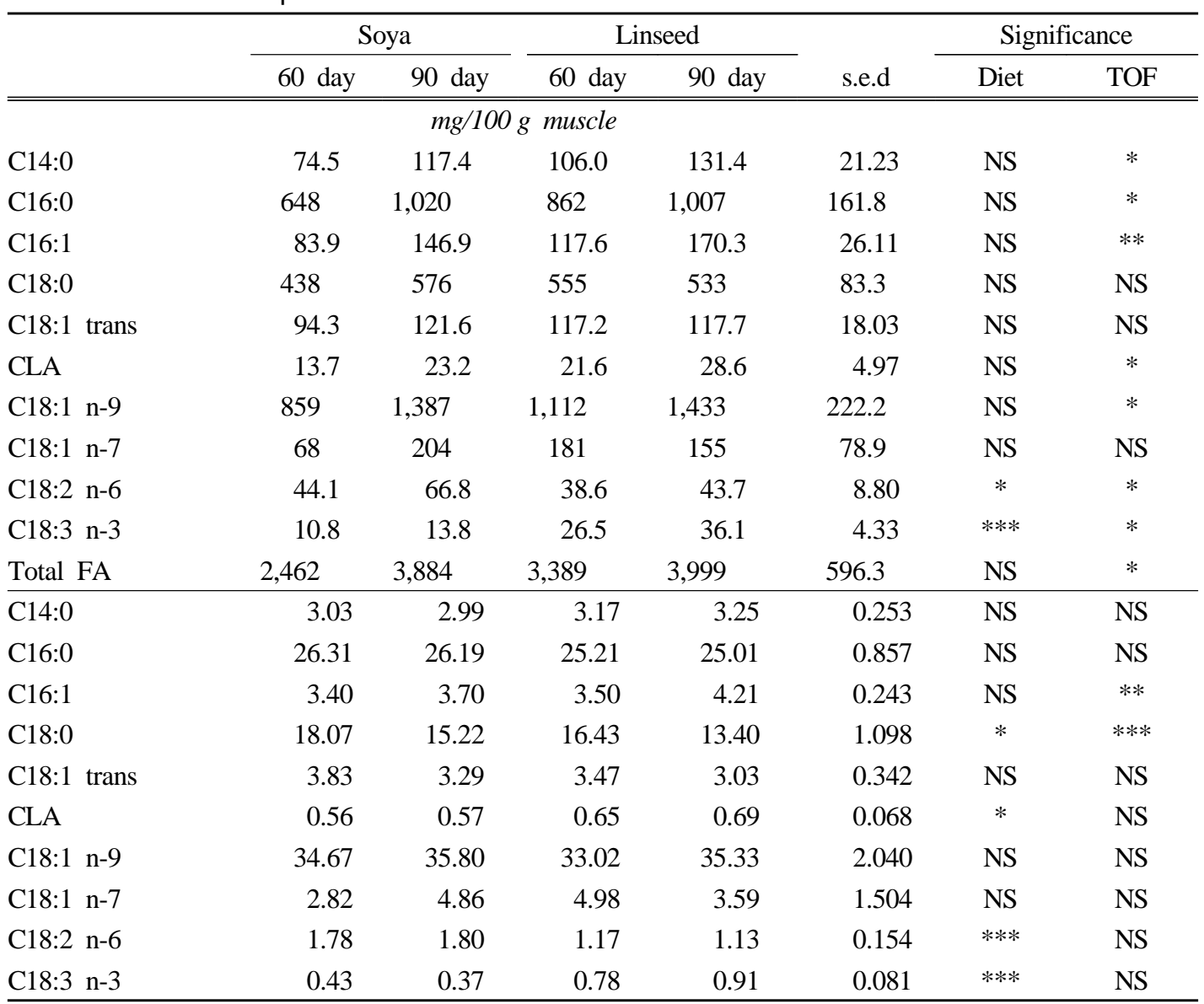


Table 5. Diet and time on feed (TOF) effects on fatty acid composition in phospholipid of $m$. longissimus thoracis tissue in Charolais steers fed on diets containing different sources of lipid

\begin{tabular}{|c|c|c|c|c|c|c|c|c|}
\hline & \multicolumn{2}{|c|}{ Soya } & \multicolumn{2}{|c|}{ Linseed } & \multirow[b]{2}{*}{ s.e.d } & \multicolumn{3}{|c|}{ Significance } \\
\hline & 60 day & 90 day & 60 day & 90 day & & Diet & TOF & Interaction \\
\hline \multicolumn{9}{|c|}{ mg/100 g muscle } \\
\hline C14:0 & 2.35 & 3.52 & 5.34 & 4.33 & 1.074 & $*$ & NS & NS \\
\hline C16:0 & 65.1 & 80.1 & 87.0 & 85.1 & 8.48 & $*$ & NS & NS \\
\hline C16:1 & 6.27 & 8.67 & 12.09 & 10.91 & 2.004 & $* *$ & NS & NS \\
\hline C18:0 & 46.7 & 55.9 & 61.8 & 59.5 & 4.91 & $*$ & NS & NS \\
\hline C18:1 trans & 4.57 & 4.56 & 7.07 & 5.28 & 0.961 & $*$ & NS & NS \\
\hline CLA & 0.71 & 0.98 & 1.38 & 1.58 & 0.316 & $* *$ & NS & NS \\
\hline C18:1 n-9 & 70.7 & 94.3 & 122.9 & 107.8 & 14.48 & $* *$ & NS & NS \\
\hline C18:1 n-7 & 9.36 & 11.03 & 8.75 & 10.93 & 0.952 & NS & $* *$ & NS \\
\hline C18:2 n-6 & 83.2 & 98.1 & 58.2 & 71.0 & 7.71 & $* * *$ & $*$ & NS \\
\hline C18:3 n-3 & 10.09 & 8.84 & 25.99 & 33.71 & 2.757 & $* * *$ & NS & $*$ \\
\hline C20:3 n-6 & 7.04 & 9.82 & 6.06 & 6.71 & 0.884 & $* *$ & $*$ & NS \\
\hline C20:4 n-3 & 1.36 & 1.42 & 3.27 & 4.21 & 0.324 & $* * *$ & $*$ & NS \\
\hline C20:4 n-6 & 23.70 & 28.48 & 23.58 & 21.81 & 2.318 & $*$ & NS & NS \\
\hline C20:5 n-3 & 9.72 & 8.25 & 14.02 & 13.93 & 1.211 & $* * *$ & NS & NS \\
\hline C22:4 n-6 & 1.52 & 2.52 & 1.22 & 1.38 & 0.295 & $* *$ & * & NS \\
\hline C22:5 n-3 & 14.09 & 15.27 & 16.78 & 19.93 & 0.974 & $* * *$ & $* *$ & NS \\
\hline C22:6 n-3 & 1.72 & 1.63 & 1.67 & 1.76 & 0.304 & NS & NS & NS \\
\hline \multirow[t]{2}{*}{ Total FA } & 415 & 505 & 529 & 528 & 43.1 & $*$ & NS & NS \\
\hline & \multicolumn{8}{|c|}{ proportion of total phospholipid fatty acid } \\
\hline C14:0 & 0.55 & 0.66 & 0.99 & 0.81 & 0.176 & $*$ & NS & NS \\
\hline C16:0 & 15.63 & 15.72 & 16.44 & 16.11 & 0.679 & NS & NS & NS \\
\hline C16:1 & 1.54 & 1.68 & 2.30 & 2.01 & 0.307 & $*$ & NS & NS \\
\hline C18:0 & 11.25 & 11.07 & 11.68 & 11.31 & 0.290 & NS & NS & NS \\
\hline C18:1 trans & 1.08 & 0.91 & 1.31 & 0.98 & 0.135 & NS & $*$ & NS \\
\hline CLA & 0.17 & 0.19 & 0.25 & 0.29 & 0.056 & $*$ & NS & NS \\
\hline C18:1 n-9 & 16.97 & 18.34 & 23.18 & 20.20 & 1.791 & $* *$ & NS & NS \\
\hline C18:1 n-7 & 2.28 & 2.20 & 1.66 & 2.12 & 0.206 & $*$ & NS & NS \\
\hline C18:2 n-6 & 20.16 & 19.72 & 10.97 & 13.61 & 1.332 & $* * *$ & NS & NS \\
\hline C18:3 n-3 & 2.43 & 1.80 & 4.90 & 6.42 & 0.364 & $* * *$ & NS & $* * *$ \\
\hline C20:3 n-6 & 1.70 & 1.93 & 1.15 & 1.28 & 0.992 & $* * *$ & $*$ & NS \\
\hline C20:4 n-3 & 0.33 & 0.28 & 0.62 & 0.79 & 0.031 & $* * *$ & $* *$ & $* * *$ \\
\hline C20:4 n-6 & 5.74 & 5.63 & 4.47 & 4.22 & 0.371 & $* * *$ & NS & NS \\
\hline C20:5 n-3 & 2.34 & 1.67 & 2.69 & 2.66 & 0.214 & $* * *$ & $*$ & $*$ \\
\hline C22:4 n-6 & 0.37 & 0.49 & 0.23 & 0.27 & 0.045 & $* * *$ & $*$ & NS \\
\hline C22:5 n-3 & 3.31 & 3.08 & 3.21 & 3.82 & 0.195 & $*$ & NS & $* *$ \\
\hline C22:6 n-3 & 0.40 & 0.33 & 0.31 & 0.34 & 0.061 & NS & NS & $\mathrm{N}$ \\
\hline
\end{tabular}


higher proportion of CLA while the proportion of C18:0 was lower on animals fed on soya. The content and proportion of C18:2 n-6 was higher on soya compared with linseed. The content of C14:0, C16:0, C16:1, CLA, C18:1 n-9, C18:2 n-6 and $\mathrm{C} 18: 3 \mathrm{n}-3$, and the proportion of $\mathrm{C} 16: 1$ and C18:0 were higher in the 90 compared with the 60 day feeding period. There were no significant interactions between diet and TOF on the fatty acid composition in neutral lipid fraction.

\section{Fatty acid composition of the muscle phospholipid fraction}

The phospholipid fraction contained higher amounts of PUFA than the neutral lipid fraction (163 v. $68 \mathrm{mg}$ per $100 \mathrm{~g}$ muscle). The content of saturated fatty acids, monounsaturated fatty acids and n-3 PUFA, except for C18:1 n-7 and C22:6 $\mathrm{n}-3$, were higher in animals fed on linseed compared to soya. Interestingly, linseed compared with soya resulted in a large increase (74\%, $\mathrm{P}<0.01$ ) in CLA, 0.85 v. $1.48 \mathrm{mg} / 100 \mathrm{~g}$ muscle, respectively, when average across TOF. Conversely, feeding linseed compared with soya resulted in a lower content of n-6 PUFA. The proportion of
C16:0, C18:0 and C18:1 trans were not different between dietary treatments.

The content and proportion of saturated and monounsaturated fatty acids were not affected by TOF, but the proportion of C18:1 trans was lower and content of n-6 PUFA higher in the 90 compared with 60 day feeding period. When expressed on a proportional basis, C18:2 n-6 and C20:4 n-6 were not affected by TOF. The content of C18:3 n-3, C20:5 n-3 and C22:6 n-3 were not affected by TOF, but that of C20:4 n-3 and C22:5 n-3 was higher in the 90 compared to 60 day feeding period. The proportion of C20:5 n-3 was lower in 90 v. 60 day feeding period. Some diet $\mathrm{x}$ TOF interaction effects were noted for n-3 PUFA proportion in phospholipid. The proportion of C18:3 n-3, C20:4 n-3 and C22:5 n-3 were higher in animals fed on linseed compared to soya and higher in 90 compared to 60 day feeding period. These n-3 PUFA were lower in animals fed on soya fed for 90 days.

\section{Nutritional indices}

Fatty acid ratios related to healthy human nutrition are presented in Table 6. The results

Table 6. Ratios of fatty acids related to healthy human nutrition in Charolais steers fed on diets containing different sources of lipid for different time periods (60 or 90 days).

\begin{tabular}{|c|c|c|c|c|c|c|c|}
\hline & \multicolumn{2}{|c|}{ Soya } & \multicolumn{2}{|c|}{ Linseed } & \multirow[b]{2}{*}{ s.e.d } & \multicolumn{2}{|c|}{ Significance } \\
\hline & 60 day & 90 day & 60 day & 90 day & & Diet & TOF \\
\hline \multicolumn{8}{|c|}{ Muscle } \\
\hline$P: S^{1)}$ & 0.11 & 0.10 & 0.09 & 0.10 & 0.014 & NS & NS \\
\hline$P: S^{2)}$ & 0.17 & 0.15 & 0.13 & 0.15 & 0.022 & NS & NS \\
\hline C18 : 2n-6/C18 : 3n-3 & 6.52 & 7.26 & 1.91 & 1.67 & 0.604 & $* * *$ & NS \\
\hline$\sum n-6: n-3^{3)}$ & 3.33 & 4.09 & 1.45 & 1.33 & 0.238 & $* * *$ & NS \\
\hline \multicolumn{8}{|c|}{ Adipose tissue } \\
\hline$P: S^{1)}$ & 0.04 & 0.05 & 0.04 & 0.04 & 0.005 & NS & * \\
\hline$P: S^{2)}$ & 0.06 & 0.07 & 0.05 & 0.06 & 0.007 & NS & NS \\
\hline C18: 2 n-6/C18: 3 n-3 & 4.27 & 4.60 & 1.40 & 1.17 & 0.288 & $* * *$ & NS \\
\hline
\end{tabular}

\footnotetext{
1) P:S calculated as (C18:2 n-6 + C18:3 n-3)/(C14:0 + C16:0 + C18:0 + C18:1 trans)

2) $\mathrm{P}: \mathrm{S}$ calculated as (C18:2 n-6 + C18:3 n-3)/(C14:0 + C16:0 + C18:1 trans)

3) $\sum n-6: n-3$ calculated as (C18:2 n-6 + C20:3 n-6 + C20:4 n-6 + C22:6 n-6)/(C18:3 n-3 + C20:4 n-3 + C20:5 n-3 + C22:5 n-3 + C22:6 n-3)
} 
were calculated from the combined results of muscle neutral lipid and phospholipid fractions. The $\mathrm{P}$ : $\mathrm{S}$ ratio has been calculated in two ways as described by Choi et al. (2000), (a) the original form which includes $\mathrm{C} 18: 0\left(\mathrm{P}: \mathrm{S}^{\dagger}\right)$ and (b) by replacing $\mathrm{C} 18: 0$ with $\mathrm{C} 18: 1$ trans $\left(\mathrm{P}: \mathrm{S}^{\ddagger}\right)$. There were no diet or TOF effects on $\mathrm{P}: \mathrm{S}$ ratios in muscle. The ratios of C18:2 n-6 : C18:3 n-3 and sum of $n-6$ : n-3 fatty acids were higher in muscle from animals fed on soya compared with linseed. In addition, an interaction effect on the sum of n-6 : n-3 fatty acids ratio in muscle was noted. In adipose tissue, the $\mathrm{P}: \mathrm{S}^{\dagger}$ ratio was higher in the 90 compared with the 60 day feeding period. The ratio of C18:2 n-6 : C18:3 $\mathrm{n}-3$ was higher in adipose from animals fed on soya compared with linseed.

\section{DISCUSSION} 1. Animal performance and carcass char-
acteristics

A higher daily liveweight gain was observed in the soya fed animals compared with the linseed fed animals. Clinquart et al. (1991) also found that daily liveweight gain was higher in soya oil fed cattle than linseed and feed conversion ratio was lower in the soya oil than the linseed treatment. As expected carcass weight, conformation and classification scores increased with TOF.

\section{Tissue fatty acid composition}

This study has shown a significant effect of diet on the n- 6 and n-3 PUFA composition of the lipids of muscle and adipose tissue of bovines. Tissues from the soya fed animals contained higher amounts of C18:2 n-6 and n-6 longer chain fatty acids, while tissues from linseed treatment contained higher amounts of C18:3 n-3 and n-3 longer chain fatty acids, respectively. This indicates that chain elongation and desaturation of dietary C18:2 n-6 and C18:3 n-3 had occurred.

\section{Diet effect}

The total content of fatty acid in muscle neutral lipid fractions and adipose tissue were not significantly different between treatments. This was different from the result observed by Marmer et al. (1984) who reported that the content of total fatty acids in the muscle and adipose tissue was lower in forage-fed steers than grain fed steers suggesting tissue from foragefed steers is leaner in comparison to grain-fed steers. However, Enser et al. (1998) reported that muscle total lipid content was higher in grass-fed steers than concentrate-fed bulls reflecting their higher carcass fatness. This can be explained by the fact that sex has a major effect on muscle total lipid content and carcass fatness, biopsy's effect than diet.

The proportion of most PUFA in muscle from soya fed animals and linseed fed animals were similar to results obtained from concentrate fed animals and forage fed animals, respectively (Marmer et al., 1984; Enser et al., 1998). However, the proportion of $\mathrm{C} 18: 3 \mathrm{n}-3$ in the phospholipid fraction from soya and linseed fed animals were approximately double those from concentrate and forage-fed animals, respectively, in Marmer's study (Marmer et al., 1984). The proportion of C18:2 n-6 in muscle from concentrate fed animals in the study of Enser et al. (1998) was also approximately double compared to soya fed animals in this study. This may be due to the different breeds, feeding periods, sexes and growth stages in the two studies.

As expected in this study, the content of C18:3 n-3 in total muscle lipid was higher in animals fed on linseed compared with soya (62 v. $22 \mathrm{mg}$ per $100 \mathrm{~g}$ muscle) reflecting higher intakes of amount of C18:3 n-3. The results were 
similar to those in the previous experiments (Choi et al., 2000; Scollan et al., 2001a,) although the proportion of C18:3 n-3 in the muscle after 60 or 90 days of feeding linseed was higher than any of the previous experiments. However, much more linseed was fed in this study hence the increased deposition of C18:3 n-3 is most likely to increased intake rather than a reduction in biohydrogenation induced by high concentrate feeding. The higher content of C18:2 n-6 and C18:3 n-3 in phospholipid fraction when feeding soya and linseed resulted in higher amounts of $n-6$ and n-3 longer chain derivatives via chain elongation and desaturation, respectively, except for C22:6 n-3.

The proportion of CLA was higher in muscle neutral and phospholipid fractions from animals fed on linseed compared with soya. Possibly, this could be explained that C18:3 n-3 in linseed is more effective than C18:2 n-6 in soya inhibiting the change from C18:2 n-6 to C18:0 during the biohydrogenation process despite the higher intake of C18:2 n-6 in the soya treatment. Other studies have also demonstrated that increasing unsaturation of fatty acids has a more negative effect on the activity of the micro-organisms in the rumen (Maczulak et al., 1981; Chalupa et al., 1984; Jenkins, 1993). Also, Sackmann et al. (2003) reported that feeding the higher level of forage which has high in C18:3 n-3 in the diet resulted in higher flows of C18:1 trans to the duodenum. Therefore, it seems that higher amounts of CLA in tissue from linseed fed animals result from higher endogenous CLA production from C18:1 trans via $\Delta^{9}$-desaturase. Gillis et al. (2003) reported that over $86 \%$ of tissue CLA in beef originates from desaturation of C18:1 trans. Apparently, the present results are in accordance to the previous observations (Sackmann et al., 2003; Gillis et al., 2003). Therefore, the present results may suggest that ruminal production of C18:1 trans and $\Delta^{9}$-desaturase activity in the tissue are crucial factors to increase CLA concentration in beef. In addition, the relationship between CLA and C18:1 trans in the muscle is shown in Figure 1, and the Figure shows a ratio of 0.20. Madron et al. (2002) and Enser et al. (1999) observed ratios of 0.23 and 0.28 , respectively. Similarly, the ratio of CLA to C18:1 trans in milk fat ranged from 0.13 to 0.46 (Jiang et al., 1996; Lawless et al., 1998; Solomon et al., 2000). While the average ratio in body fat was relatively lower than that of milk fat (0.24 vs 0.32$)$ due to possibly genetic difference between beef and dairy cattle. As in the muscle, the proportion of both C18:2 n-6 and C18:3 n-3 were also significantly different in adipose tissue between the treatments reflecting dietary fatty acids.

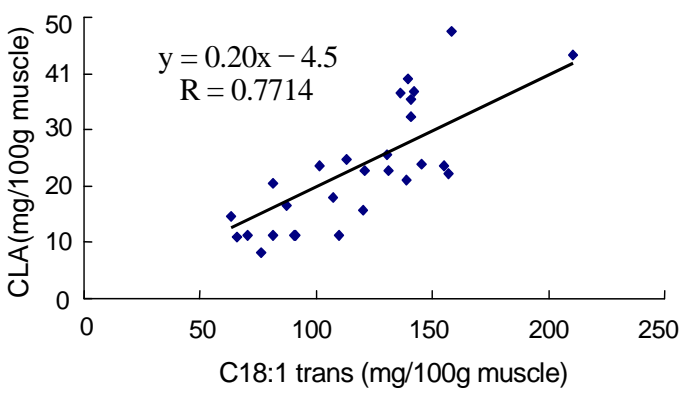

Fig. 1. The relationship between CLA and C18:1 trans in muscle.

In the present results showed that CLA content in the muscle was higher in linseed treatment compared with soya treatment (6.3 vs $5.3 \mathrm{mg} / \mathrm{g}$ of fatty acid). The CLA content in the muscle was similar to previous results reported with linseed oil and fish oil (5.7-8.0 mg/g of fatty acid; Enser et al., 1999), extruded full fat soybean (6.6-7.7 $\mathrm{mg} / \mathrm{g}$ of fatty acid; Madron et al., 2002), and ruminally protected lipid (4.1-4.6 mg/g of fatty acid; Scollan et al., 2003). Relative low contents of muscle CLA was observed in work of Scollan et al. (2003) reflecting dietary fatty acids were well protected in the rumen. 


\section{Time on feed effect}

Total fatty acid in the neutral lipid fraction was increased as the TOF increased, which was in agreement with the result from Duckett et al. (1993). Increased total fatty acid in the neutral lipid reflects increased total muscle lipid (neutral lipid plus phospholipid fraction), as the phospholipid fraction remains fairly constant (Duckett et al., 1993). In addition, the content of CLA in the muscle was increased as the TOF increased (5.5 vs $6.1 \mathrm{mg} / \mathrm{g}$ of fatty acid) due to CLA concentration was diluted with increased total fatty acid in the muscle. The effect of age on fatty acid composition in beef is also related to body fatness (Robelin, 1986; Huerta-Leidenz et al., 1996). As in the above studies, these results also showed that total fatty acids, based on fatness, increased as TOF increased. However, unsaturated fatty acids in the muscle did not increase as TOF increased. Instead the proportion of muscle unsaturated C18 fatty acids, the major unsaturated fatty acids, remained constant with TOF. There was a tendency for the saturated fatty acids in muscle to decrease, reflecting mainly a decrease in the proportion of C18:0. Hecker et al. (1975) observed that there was an apparent increase in monounsaturated fatty acids and a corresponding decrease in saturated fatty acids in muscle, as the animals grew, mainly due to an inverse relationship between C18:0 and C18:1. The proportion of C18:1 n-9 increases gradually but not significantly in this study although the decline in C18:0 was marked.

The amount of total fatty acid in adipose tissue did not increase as TOF increased. This is not in agreement with the result of Hecker et al. (1975) who observed that the amount of subcutaneous adipose tissue fat increased markedly during growth and fattening. This result may be due to differences in feeding time between the studies.

\section{Impact on human nutrition}

As the previous experiments have shown (Choi et al., 2000; Scollan et al., 2001a), the implications of the results for human nutrition are difficult to assess. The P:S ratios in muscle were lower than the recommended ratio $(<0.45)$, on average approximately 0.13 . Similarly, other studies reported that P:S ratio in muscle ranged 0.04 to 0.17 (mean ratio 0.11) (Madron et al., 2002; French et al., 2000; Choi et al., 2000; Scollan et al., 2001a). While, Scollan et al. (2003) observed a relatively higher P:S ratio (0.19-0.41) due to a high degree of protection from the hydrogenating action of rumen micro-organisms. In adipose tissue, this ratio was also lower than the recommended ratio. $\mathrm{P}: \mathrm{S}^{\dagger}$ was higher in the 90 $\mathrm{d}$ feeding group in comparison to the $60 \mathrm{~d}$ feeding group. This was due to the unsaturation of fatty acid increasing as the TOF increased.

Since meat and fish are the only significant sources of preformed longer-chain n-3 PUFA in human food and an increase in their consumption has been recommended (Department of Health, 1994) it would seem preferable to maintain or improve the $n-6: n-3$ fatty acids ratio in beef rather than increase the $\mathrm{P}: \mathrm{S}$ ratio by feeding dietary n-3 fat sources. Although the concentrations of the longer-chain n-3 PUFA in meat are low compared with oily fish, consumption of lean beef over several weeks has been demonstrated to alter the plasma PUFA composition (Sinclair et al., 1994). In this study, the $n-6$ to $n-3$ fatty acid ratios were higher in muscle and adipose tissue from steers fed on soya than linseed. C18:2 n-6/C18:3 n-3 ratio in the muscle was on average 6.89 in soya and 1.39 in linseed treatment. This is due to the higher amounts of C18:2 n-6 arising from the soya, and its n-6 longer chain fatty acids being produced via chain elongation and desaturation from C18:2 n-6. Similarly, C18:2 n-6/C18:3 n-3 in the muscle 
was lowest in the all forage-fed treatment compared with different levels of concentrates-fed animal treatments (2.33: grass $22 \mathrm{~kg}$ vs 3.61 : grass silage $5.8 \mathrm{~kg}+$ concentrate $3.6 \mathrm{~kg}$, 4.15: hay $1 \mathrm{~kg}+$ concentrate $8 \mathrm{~kg}, 2.86$ : grass $6 \mathrm{~kg}+$ concentrate $5 \mathrm{~kg}$, or 2.47: grass $12 \mathrm{~kg}+$ concentrate $2.5 \mathrm{~kg}$ ) (French et al., 2000).

\section{CONCLUSIONS}

This study clearly indicates that PUFA composition of bovine tissue was affected by differences between the fatty acid composition of soya and linseed. Linseed was more beneficial for human nutrition, due to lower C18:2 n-6 /C18:3 n-3 ratio, higher C20:5 n-3, lower C20:4 n-6 and higher CLA in muscle from linseed fed steers. PUFA composition in soya fed animals was similar to that of concentrate fed animals and linseed fed animals was similar to forage fed animals. There was a strong preference for the incorporation of n-6 PUFA into beef muscle phospholipids. The P:S ratios were difficult to increase to the recommended value due to high levels of ruminal biohydrogenation. Total intramuscular fatty acid increased as time on feed increased, but there was little effect on the percentages.

\section{ABSTRACT}

This study investigated the effects of feeding Charolais steers on diets rich in either n- 6 or $n-3$ polyunsaturated fatty acids (PUFA) and time on feed (TOF) on muscle fatty acid composition and content. Twenty eight steers were fed on ad libitum forage and one of two concentrates varying in the source of fat; soya (high in C18:2 $\mathrm{n}-6)$ or whole linseed (high in C18:3 n-3) for either 60 or 90 days in IGER (Institute of Grassland and Environmental Research, UK). The concentrates were fed at approximately 0.73 of total DM intake. TOF influenced carcass weight, conformation and fatness scores, which were higher at 90 v. 60 days $(\mathrm{P}<0.05)$. Diet did not affect total fatty acid content of neutral lipid in $m$. longissimus thoracis but feeding linseed increased total phospholipid fatty acid by approximately $15 \%(\mathrm{P}<0.05)$. Linseed increased the amount and proportion of $\mathrm{C} 18: 3 \mathrm{n}-3 \quad(\mathrm{P}<0.001)$ and the proportion of CLA (cis-9, trans-11 conjugated linoleic acid), while soya increased the content $(\mathrm{P}<0.05)$ and proportion $(\mathrm{P}<0.001)$ of $\mathrm{C} 18: 2 \mathrm{n}-6$ in muscle neutral lipid. In muscle phospholipid, linseed significantly increased the amount of CLA, C18:3 n-3 and its longer chain derivatives as well as C14:0, C16:0, C18:0. C18:1 trans and C18:2 n-6. The amount and proportion of C18:2 n-6 and its longer chain C20 derivatives were higher on feeding soya. TOF (90 v. 60 day) increased the content of C14:0, C16:0, C16:1, CLA, C18:1 n-9, C18:2 n-6 and C18:3 n-3 in muscle neutral lipid. The P:S was not affected by diet or TOF. The ratio of C18:2 n-6 : C18:3 n-3 and sum of n-6 : n-3 fatty acids were higher in muscle from animals fed on linseed $v$. soya $(\mathrm{P}<0.001)$. The study indicates that the PUFA composition of beef muscle may be significantly modified by feeding contrasting dietary lipids, soya vs. linseed. Feeding linseed produced a better balance of muscle fatty acids, more in line with current nutritional recommendations with a lower C18:2 n-6:C18:3 n-3 ratio associated with higher muscle content of C18:3 n-3 and C20:5 n-3 and CLA and lower C20:4 n-6.

(Key words: Beef, Lipids, Polyunsaturated fatty acids)

\section{ACKNOWLEDGMENTS}

We are grateful to the staff of Gogerddan Beef Research Unit for the care of the animals and to all staff who assisted with laboratory analysis at both IGER and the University of Bristol. This work was supported by Department 
for Environment, Food and Rural Affairs with support from ABN Ltd, Pedigree Pet Foods, Roche Products Limited, Rare Breeds Survival Trust and Tesco Stores Ltd.

\section{REFERENCES}

1. Chalupa, W., Rickabaugh, B., Kronfeld, D. S. and Sklan, D. 1984 . Rumen fermentation in vitro as influenced by long chain fatty acids. Journal of Dairy Science 67:1439-1444.

2. Choi, N. J., Enser, M., Wood, J. D. and Scollan, N. D. 2000. Effect of breed on the deposition in beef muscle and adipose tissue of dietary n-3 polyunsaturated fatty acids. Animal Science 71: 509-519.

3. Clinquart, A., Istasse, L., Dufrasne, I., Mayombo, A., van Eenaeme, C. and Bienfait, J. M. 1991. Effects on animal performance and fat composition of two fat concentrates in diets for growingfattening bulls. Animal Production 53:315-320.

4. Department of Health. 1994. Report on health and social subjects No. 46. Nutritional aspects of cardiovascular disease. HMSO, London.

5. Duckett, S. K., Wagner, D. G., Yates, L. D., Dolezal, H. G. and May, S. G. 1993. Effects of time on feed on beef nutrient composition. Journal of Animal Science 71:2079-2088.

6. Enser, M., Hallett, K. G., Hewett, B., Fursey, G. A. J., Wood, J. D. and Harrington, G. 1998. Fatty acid content and composition of UK beef and lamb muscle in relation to production system and implications for human nutrition. Meat Science 49:329-341.

7. Enser, M., Scollan, N. D., Choi, N. J., Kurt, E., Hallett, K. and Wood, J. D. 1999. Effect of dietary lipid on the content of conjugated linoleic acid (CLA) in beef muscle. Animal Science. 69:143-146

8. French, P., Stanto, C., Lawless, F., O’Ricordan, E. G., Monahan, F. J., Caffrey, P. J. and Moloney, A. P. 2000. Fatty acid composition, including conjugated linoleic acid, of intramuscular fat from steers offered grazed, grass silage, or concentratebased diets. Journal of Animal Science. 78:28492855.

9. Gillis, M. H., Duckett, S. K., Sackmann, J. S. and Keisler, D. H. 2003. Effect of rumenprotected conjugated linoleic acid (CLA) or linoleic acid on leptin and CLA content of bovine adipose depots. Journal of Animal Science. 81 (suppl. 2):12 (Abstract)

10. Hansen, H. S. 1994. New biological clinical roles for the $n-6$ and $n-3$ fatty acids. Nutrition Reviews 52:162-167.

11. Hecker, A. L., Cramer, D. A. and Hougham, D. F. 1975. Compositional and metabolic growth effects in the bovine muscle, subcutaneous and serum total fatty acids. Journal of Food Science 40:144-149.

12. Huerta-Leidenz, N. O., Cross, H. R., Savell, J. W., Lunt, D. K., Baker, J. F. and Smith, S. B. 1996. Fatty acid composition of subcutaneous adipose tissue from male calves at different stages of growth. Journal of Animal Science 74:12561264.

13. Jenkins, T. C. 1993. Lipid metabolism in the rumen. Journal of Dairy Science 76:3851-3863.

14. Jiang, J., Bjöerck, L., Fonden, R. and Emanuelson, M. 1996. Occurrence of conjgated cis-9, trans-11 octadecadienoic acid in bovine milk: effects of feed and dietary regimen. Journal of Dairy Science. 79:438-445.

15. Kempster, A. J., Cook, G. L. and Grantley-Smith, M. 1986. National estimates of the body composition of British cattle, sheep and pigs with special reference to trends in fatness. A review. Meat Science 17:107-138.

16. Lawes Agricultural Trust. 1990. GENSTAT V mark 2.2. Rothamsted Experimental Station, Harpenden, UK.

17. Lawless, F., Murphy, J. J., Harrington, D., Devery, R. and Stanton, C. 1998. Elevation of conjugated cis-9, trans-11-octadecadienoic acid in bovine milk because of dietary supplementation. 
Journal of Dairy Science. 81:3259-3267.

18. Link, B. A., Bray, R. W., Cassens, R. G. and Kauffman, R. G. 1970. Fatty acid composition of bovine skeletal muscle lipids during growth. Journal of Animal Science 30:726-731.

19. Maczulak, A. E., Dehority, B. A. and Palmquist, D. L. 1981. Effects of long-chain fatty acids on growth of rumen bacteria. Applied and Environmental Microbiology 42:856-862.

20. Madron, M. S., Peterson, D. G., Dwyer, D. A., Corl, B. A., Baumgard, L. H., Beermann, D. H. and Bauman, D. E. 2002. Effect of extruded fullfat soybeans on conjugated linoleic acid content of intramuscular, intermuscular, and subcutaneous fat in beef steers. Journal of Animal Science. 80:1135-1143.

21. Marmer, W. N., Maxwell, R. J. and Williams, J. E. 1984. Effects of dietary regimen and tissue site on bovine fatty acid profiles. Journal of Animal Science 59:109-121.

22. Robelin, J. 1986. Growth of adipose tissues in cattle; portioning between depots, chemical composition and cellularity. Review of Livestock Production Science 14:349-364.

23. Rule, D. C., MacNeil, M. D. and Short, R. E. 1997. Influence of sire growth potential, time on feed and growing-inishing strategy on cholesterol and fatty acids of the ground carcass and longissimus muscle of beef steers. Journal of Animal Science 75:1525-1533.

24. Sackmann, J. R., Duckett, S. K., Gillis, M. H., Realini, C. E., Parks, A. H. and Eggelston, R. B. 2003. Effects of forage and sunflower oil levels on ruminal biohydrogenation of fatty acids and conjugated linoleic acid formation in beef steers fed finishing diets. Journal of Animal Science. 81:3174-3181.
25. Scollan, N. D., Choi, N, J., Kurt, E., Fisher, A. V., Enser, M. and Wood, J. D. 2001a. Manipulating the fatty acid composition of muscle and adipose tissue in beef cattle. British Journal of Nutrition 85:115-124.

26. Scollan, N. D., Choi, N, J., Maeng, W. J., Enser, M. and Wood, J. D. 2001b. Digestion of long chain fatty acids from different feed sources and their effect on the rumen function of steers. Journal of Agricultural Science, Cambridge, 136: 345-355.

27. Scollan, N. D., Enser, M., Gulati, S. K., Richardson, I. and Wood, J. D. 2003. Effects of including a ruminally protected lipid supplement in the diet on the fatty acid composition of beef muscle. British Journal of Nutrition. 90:709-716.

28. Sinclair, A. J., Johnson, L., O’Dea, K. and Holman, R. T. 1994. Diets rich in lean beef increase arachidonic acid and long chain $\omega-3$ polyunsaturated fatty acids levels in plasma phospholipids. Lipids 29:337-343.

29. Solomon, R., Chase, L. E., Ben-hedalia, D. and Bauman, D. E. 2000. The effect of non-structural carbohydrate and addition of full fat extruded soybeans on the concentration of conjugated linoleic acid in the milk fat of dairy cows. Journal of Dairy Science. 83:1322-1329.

30. Van Nevel, C. J. and Demeyer, D. I. 1996a. Influence of $\mathrm{pH}$ on lipolysis and biohydrogenation of soybean oil by rumen contents in vitro. Reproduction Nutrition Development 36:53-63.

31. Westerling, D. B. and Hedrick, H. B. 1979. Fatty acid composition of bovine lipids as influenced by diet, sex and anatomical location and the relationship to sensory characteristics. Journal of Animal Science 48:1343-1348.

(접수일자 : 2006. 8. 25. / 채택일자 : 2006. 11. 20.) 